\title{
The Effect of Clonidine Drip in Hypertensive Crisis in Children
}

\author{
H. Alatas, Huda Farida, I.G.N Wila Wirya, T. Tambunan, P. Trihono
}

\begin{abstract}
Abstrak
Drip klonidin diberikan pada 17 kasus hipertensi ( 9 mengalami ensefalopati hipertensif) yang dirawat di Bagian llmu kesehatan Anak FKUI/RSCM dari Maret 1990 sampai Pebruari 1993. Penyakit dasar penderita ialah : 7 dengan glomerulonefritis akut, 4 gagal ginjal kronik, 2 infeksi saluran kemih kompleks, 1 penyakit Takayasu, 1 meningitis virus, 1 gagal jantung (MI, MS, ec RHD) dan 1 etiologi tak diketahui. Drip klonidin diberikan secara titrasi, dimulai dengan dosis $0,002 \mathrm{mg} / \mathrm{kgBB} / 8$ jam dalam $100 \mathrm{cc}$ dekstrosa $5 \%$ dengan tetesan awal 12 tetes/menit bersama dengan furosemid $\mathrm{V} 1 \mathrm{mg} / \mathrm{kg} B B / 8 \mathrm{jam}$. Tetesan dinaikkan dengan kelipatan 6 tetes setiap 30 menit hingga dosis maksimal 36 tetes/menit $(0,006 \mathrm{mg} / \mathrm{kgBB})$ sampai tekanan diastolik turun $\leq 100 \mathrm{~mm} \mathrm{Hg}$ atau $\mathrm{MAP} \leq 93 \mathrm{~mm} \mathrm{Hg}$. Bila hal ini belum tercapai di tambah dengan kaptopril oral. Usia penderita berkisar antara 5 - 13 tahun (rata-rata $97 / 12$ tahun), laki-laki 9, perempuan 8 orang. Setelah 30 menit pemberian klonidin terdapat penurunan tekanan darah pada 4 kasus (23,5\%), 1 jam pada 5 kasus (29,5\%), 3 jam pada 7 kasus (41,2\%), 6 jam pada 11 kasus $(64,7 \%) 12$ jam pada 14 kasus (82,3\%) dan lebih dari 24 jam pada 3 kasus (17,6\%). Dengan dosis klonidin 0,002 mg/kgBB tekanan darah dapat diturunkan pada 3 kasus (17,6\%), dosis 0,004 $\mathrm{mg} / \mathrm{kgBB}$ pada 4 kasus $(23,5 \%)$, dan dosis $0,006 \mathrm{mg} / \mathrm{kg} B$ B pada 10 kasus $(58,9 \%)$. Pada satu kasus ditambah kaptopril oral karena setelah diberi klonidin dosis maksimal tekanan darah belum turun. Tekanan darah turun secara bertahap sejak 30 menit setelah pemberian klonidin dan setelah 6 jam pemberian klonidin tekanan sistolik turun 24,3\%, diastolik 27\% dan MAP 29,7\%. Dalam 24 jam pertama tekanan darah diastolik turun $\leq 100 \mathrm{mmHg}$ pada 14 dari 17 penderita. Selama penelitian tidak dijumpai gejala efek samiping obat yang jelas. Disimpulkan bahwa drip klonidin bermanfaat untuk menurunkan tekanan darah secara cepat pada krisis hipertensi.
\end{abstract}

\begin{abstract}
Clonidine drip was given to 17 patients with hypertensive crisis (9 cases showed hypertensive encephalopathy) admitted to the Department of Child Health of the Cipto Mangunkusumo Hospital during a 3-year perod (March 1990 until February 1993). Various etiologies of the hypertension were encountered : 7 cases were due to acute glomerulonephritis, 4 with chronic renal failure, 2 complicated urinary tract infection, I Takayasu's disease, 1 viral meningitis, 1 acute cardiac decompensation (rhemmatic heart disease) and 1 of unknown etiology. Clonidine was administered by titration with an initial dose of $0.002 \mathrm{mg} / \mathrm{kgBW}$ every 8 hours in a $100 \mathrm{ml}$ $5 \%$ dextrosa solution, together with furosemide $1 \mathrm{mg} / \mathrm{kgBW}$ given every 8 hours intravenously. The drip was increases every $1 / 2$ hour until the diastolic pressure decreased to less than $100 \mathrm{mmHg}$ or the mean arterial pressure (MAP) reached less than $93 \mathrm{mmHg}$. The maximal dose of clinidine was $0.006 \mathrm{mg} / \mathrm{kg} B \mathrm{~W} / 8$ hours. If no reduction in diastolic pressure was obtained until the maximal dose was reached, captopril was supplemented orally. The age of the children was between 5-13 years (mean age 9 7/12), comprising of 9 boys and 8 girls. The results of treatment showed that blood pressure decreased in 4 cases (23,5\%) after 30 minutes, 5 cases $(29,5 \%)$ after 1 hour, 7 cases $(41.2 \%)$ after 3 hours, 11 cases $(64.7 \%)$ after 6 hours, 14 cases $(82.3 \%)$ after 12 hours while in 3 cases (17.6\%) it decreased after 24 hours of clonidine administration. The clonidine dosage used in this study was $0,002 \mathrm{mg} / \mathrm{kg} B W$ in 3 cases $(17,6 \%), 0,004$ $\mathrm{mg} / \mathrm{kgBW}$ in 4 cases $(23.5 \%)$ and $0.006 \mathrm{mg} / \mathrm{kgBW}$ in 10 cases $(58.9 \%)$. Captopril was added orally in only 1 case. The onset of effect upon the blood pressure was 30 minutes after clonidine administration. After 6 hours of administration the systolic blood pressure decreased $24.3 \%$ the diastolic blood pressure 27\% and MAP $29.7 \%$. Within 24 hours 14 out of 17 cases showed a decrease in diastolic blood pressure less than $100 \mathrm{~mm} \mathrm{Hg}$. No obvious side effect was detected during the study. In conclusion clinidine drip showed a promising effect in the treatment of hypertensive crisis in children.
\end{abstract}

Keywords : Clonidine drip, Hypertensive crisis, Hypertensive encephalopathy

\section{IN'TRODUCTION}

Hypertensive crisis in children is a relative rare emergency condition, which is in accordance with the incidence of hypertension in children which is less frequent compared to adults.
Up till now there is no report available concerning the incidence of hypertensive crisis ir. children in Indonesia. Alatas et al ${ }^{\prime}$ reported 12 cases with hypertensive crisis during a 3-years observation among 78 patients with renal hypertension in children. In the last 
few years much attention has been given to hypertension in children. This is attributed to the notion that many victims of adult hypertension started since childhood or adolescence. In Jakarta the prevalence of hypertension in children is about $3.11 \%^{2}$ while in adults it is $14.2 \% .^{3}$

Hypertension in children is often secondary and the morbidity is associated with the primary disease. The presence of hypertensive crisis in children is considered an emergency condition and the blood pressure has to be reduced as soon as possible to prevent unexpected complications, such as hypertensive encephalopathy. If a patient with hypertensive crisis is not managed properly, most of them will die within a period of 6 months. ${ }^{4}$

The objective of this study was to evaluate the effect of clonidine in 17 hypertensive crisis in children with various etiologies and with special attention to the time lag of lowering the blood pressure, drug dosage and the possible side effect encountered during the treatment.

\section{PATIENTS AND METHODS}

To all children with the diagnosis of hypertensive crisis, admitted to the Child Health Department, Faculty of Medicine, University of Indonesia, Dr. Cipto Mangunkusumo Hospital, Jakarta, during the period of March 1990 up till February 1993, were given clonidine drips as treatment.

In this study hypertensive crisis was defined as a systolic blood pressure of $180 \mathrm{mmHg}$ or more and a diastolic pressure of $120 \mathrm{mmHg}$ or more or when the systolic pressure was less than $180 \mathrm{mmHg}$, and the diastolic pressure less than $120 \mathrm{mmHg}$, but accompanied by symptoms of encephalopathy, cardiac decompensation or papil edema of the eyes.

The patients were treated according to a standard protocol at our Child Health Department, i.e. titration of clonidine drip with a starting dose from 0.002 $\mathrm{mg} / \mathrm{kgBW}$ every 8 hours in $100 \mathrm{ml} \mathrm{5 \%}$ dextrose with an initial drip of 12 per minute along with IV furosemide of $1 \mathrm{mg} / \mathrm{kgBW}$ every 8 hours.

The drip were increased 6 drips every 30 minutes until a maximal of $36 \mathrm{drips} / \mathrm{min}$ was reached $(0.006$ $\mathrm{mg} / \mathrm{kgBW}$ ) and the diastolic decreased to $100 \mathrm{mmHg}$ or less or the maximum arterial pressure (MAP) to less than $93 \mathrm{mmHg}$. If with this mode of treatment the expected decrease in diastolic pressure was not reached, additional oral captopril with an initial dose of $0.3 \mathrm{mg} / \mathrm{kgBW} /$ time, $2-3$ times daily was given and if necessary this dose could be increased to a maximum of $2 \mathrm{mg} / \mathrm{kgBW}$ each time. ${ }^{5}$

Observation and evaluation were done to the amount of drug required, the time lag between the introduction of the drug and the lowering of diastolic blood pressure to reach $100 \mathrm{mmHg}$ or less or the MAP less than $93 \mathrm{mmHg}$, and the possible side effects of the drug.

\section{RESULTS}

Since March 1990 till March 1993, 17 cases of hypertensive crisis fulfilled the criteria of diagnosis, comprising 9 boys and 8 girls.

The distribution of patients each year was depicted in Figure 1. The age of patients ranged from 5-13 years with a mean of $97 / 12$ years. From the 27 patients with hypertensive crisis the most common cause was acute glomerulonephritis (AGN) i.e. 7 out of 17 cases and most of their ages were between 5-7 years old, which consisted of 5 patients. While patients with chronic renal failure (CRF) were encountered at older ages (11-13 years) i.e. 3 out of 4 patients (Table 1).

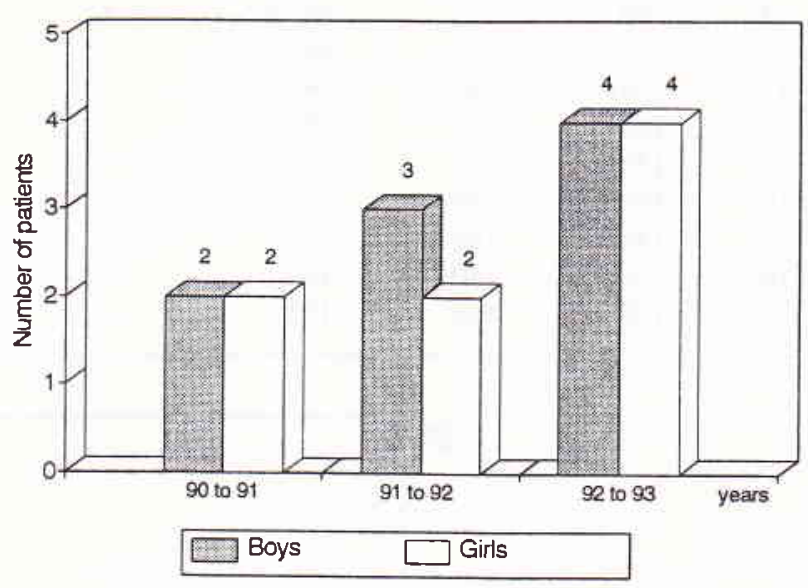

Figure 1. Annual distribution of hypertensive patients according to sex, compiled within 3 years, from March 1990 till February 1993.

Table 1. Distribution of hypertensive patients according to and their primary diseases

\begin{tabular}{lcccc}
\hline & \multicolumn{5}{c}{ Age } \\
Primary disease & $5-7$ years & $8-10$ ycars & $11-13$ years & Total \\
\hline AGN & 5 & 2 & & 7 \\
CRF & & 1 & 3 & 4 \\
Complicated UTI & 1 & & 2 & 2 \\
Takayasu`s discase & & & 1 & 1 \\
Viral meningitis & & 1 & & 1 \\
Cardiac decompensation & & & 1 & 1 \\
Unknown & 6 & 4 & 7 & 17 \\
\hline Total & & &
\end{tabular}


From Table 2 it could be seen the height of the hypertension on admission. Hypertensive encephalopathy was found in 9 cases.

After 30 minutes of clonidine drip the systolic pressure reduced to $7.2 \%$, the diastolic pressure reduced to $3.4 \%$ and the MAP to $5.5 \%$ in 4 cases (23.3\%).

Table 2. Distribution of the height of blood pressure on 17 patients on admission with or without symptoms of hypertensive encephalopathy

\begin{tabular}{rcclc}
\hline No. & Systolic & Diastolic & MAP & Encephalopathy \\
\hline 1. & 180 & 120 & 150 & + \\
2. & 150 & 110 & 130 & + \\
3. & 170 & 120 & 145 & + \\
4. & 200 & 140 & 170 & + \\
5. & 210 & 120 & 165 & + \\
6. & 190 & 140 & 165 & - \\
7. & 180 & 115 & 147.5 & + \\
8. & 190 & 120 & 155 & - \\
9. & 160 & 125 & 142.5 & + \\
10. & 200 & 125 & 162.5 & - \\
11. & 160 & 120 & 140 & + \\
12. & 180 & 120 & 150 & - \\
13. & 155 & 115 & 135 & + \\
14. & 190 & 120 & 155 & - \\
15. & 180 & 120 & 150 & - \\
16. & 230 & 130 & 180 & - \\
17. & 190 & 120 & 155 & - \\
\hline
\end{tabular}

After 1 hour treatment the systolic blood pressure decreased to $8 \%$, the diastolic pressure to $7.5 \%$ and MAP to $7.8 \%$ in 5 cases (29.4\%). After 3 hours the systolic blood pressure decreased to $23.6 \%$, diastolic pressure to $21.5 \%$ and MAP to $22.5 \%$ in 7 cases (41.2\%). After 6 hours the systolic blood pressure decreased to $24.3 \%$, diastolic pressure to $27.0 \%$ and MAP decreased to $24.9 \%$ in 11 cases $(64.7 \%)$. After 12 hours the systolic blood pressure was decreased to $36.4 \%$, the diastolic pressure to $35,1 \%$ and the MAP decreased to $36,0 \%$ in 14 cases $(82.4 \%$ ). In 3 cases $(17.6 \%)$ the systolic and diastolic blood pressure together with the MAP reached the expected height after 24 hours (Figure 2 and Table 3).

In one case additional oral captopril was given after the introduction of clonidine drip with a dose of $0.006 \mathrm{mg} / \mathrm{kgBW}$, when the diastolic blood pressure and MAP did not reached the expected decline.

Table 3. Distribution of percentage of declining systolic and diastolic blood pressure and MAP according to the time clonidine was given.

\begin{tabular}{lrrr}
\hline \multicolumn{1}{c}{ Time } & $\begin{array}{l}\text { Systolic } \\
\text { Pressure }\end{array}$ & $\begin{array}{l}\text { Diastolic } \\
\text { Pressure }\end{array}$ & MAP \\
\hline 30 minutes & $7.2 \%$ & $3.4 \%$ & $5.5 \%$ \\
1 hour & $8.0 \%$ & $7.5 \%$ & $7.8 \%$ \\
3 hours & $23.6 \%$ & $21.5 \%$ & $22.5 \%$ \\
6 hours & $24.3 \%$ & $27.0 \%$ & $24.9 \%$ \\
12 hours & $36.4 \%$ & $35.1 \%$ & $36.0 \%$ \\
\hline
\end{tabular}

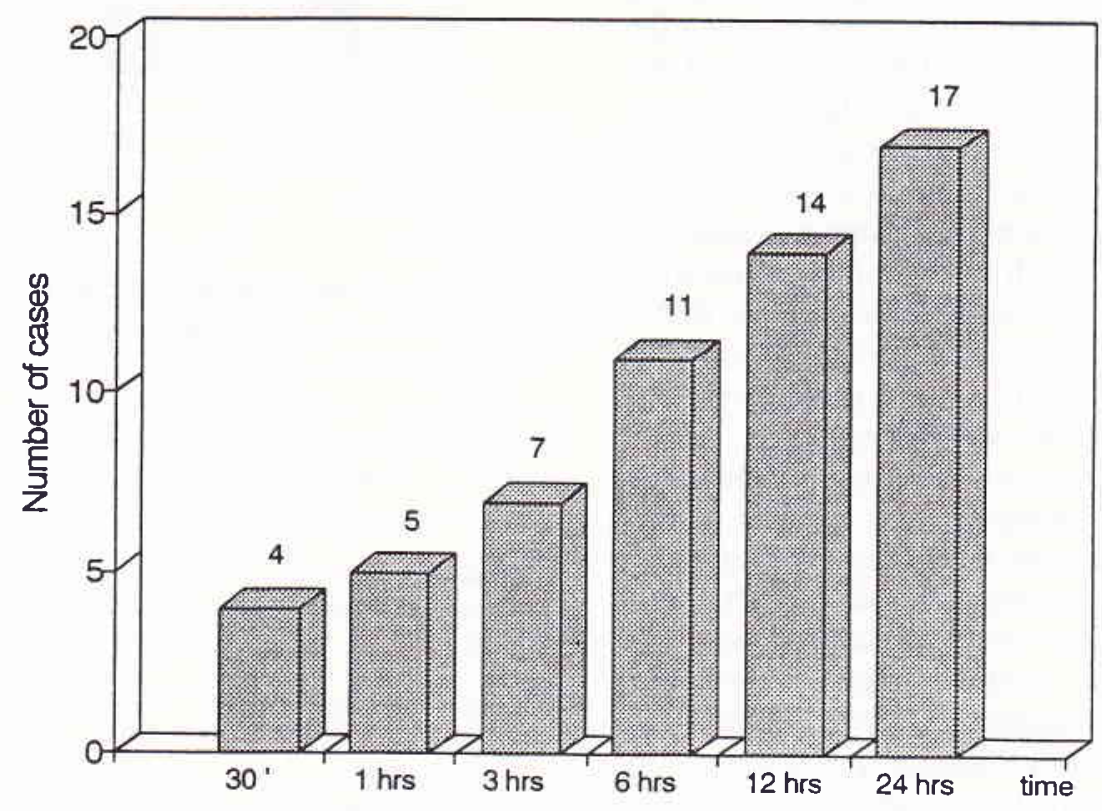

Figure 2. Distribution of the number of patients who reached the diastolic pressure of less than $100 \mathrm{mmHg}$ according to the time when clonidine was introduced. 
Table 3 showed the percentage of reduction in systolic and diastolic blood pressure along with the MAP after clonidine introduction for 30 minutes, 1, 3, 6 and 12 hours.

It was evident that from the dosis of clonidine introduced the blood pressure could be decreased in 3 cases $(17.6 \%$ ) with $0.002 \mathrm{mg} / \mathrm{kgBW}$, and 4 cases $(23.5 \%)$ with a dose of $0.004 \mathrm{mg} / \mathrm{kgBW}$ and 10 cases ( $₹ 8.9 \%$ ) with $0.006 \mathrm{mg} / \mathrm{kgBW}$ (Figure 3 ).

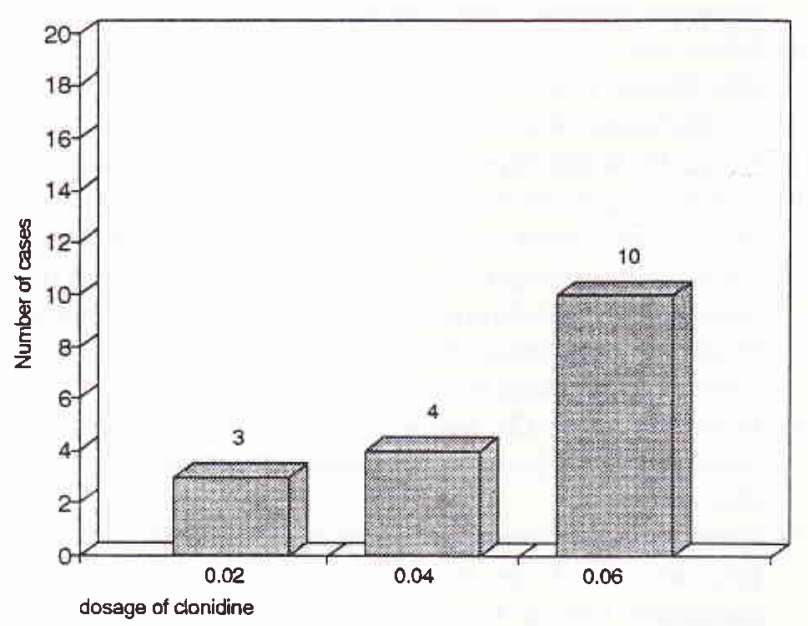

Figure 3. Distribution of blood pressure decrease in 17 cases in relation with clonidine dosage.

During the study no serious side effect like bradycardia was encountered. In 3 children drowsiness was found, but it was still doubtful whether it was due to the drug or to the severity of the underlying disease.

\section{DISCUSSION}

Since the last 5 years clonidine drip treatment has been introduced to hypertensive crisis patients in the Pediatric Nephrology Ward, Cipto Mangunkusumo Hospital, Jakarta. During the period of March 1990 until February 1993, 17 cases of hypertensive crisis were detected and received clonidine drip treatment according to the standard protocol. Figure 1 showed that there was a tendency of increasing number of patients with this disease from year to year.

Most hypertensive cases in children $( \pm 85 \%)$ are secondary in origin, expecially caused by parenchymal renal disease. ${ }^{4,6}$.

As shown in this study the most common cause was acute glomerulonephritis at the ages between 5-7 years (5 cases) and chronic renal failure at older ages, 11-13 years ( 3 cases). In one case the cause of hypertension could not be determined and was considered as an essential one.
From the previous study, during a 3-year period, 78 cases with renal hypertension were encountered. Of these 12 were hypertensive crisis patients, 7 were caused by AGN, 1 case with nephrotic syndrome, 1 chronic pyelonephritis and 3 with renovascular hypertension.

Out of the 17 cases with hypertensive crisis during the 3-year study, 9 cases $(52.9 \%)$ showed symptoms of hypertensive encephalopathy. This finding was in accordance with the report in the literature that hypertensive encephalopathy was the most common complication encountered in children. ${ }^{7,8}$

Regardless of the etiology, hypertensive crisis is considered a condition which need an immediate and intensive management. The objective of the treatment of these cases is to lower the blood pressure as soon as possible to normal in order to prevent the possible complication caused by the very high and long lasting blood pressure such as the target organs of namely the brain, heart, eyes and the kidneys.

Until recently there is still conflicting evidence of how low the blood pressure has to be decreased. Zimmerman $^{9}$ suggested a lowering of the blood pressure until the mean arterial pressure was about $120 \mathrm{mmHg}$, a decrease in systolic pressure $20-40 \%$ or a diastolic pressure of $100 \mathrm{mmHg}$.

On the other hand Kaplan ${ }^{4}$ proposed a decreased of $25 \%$ of the blood pressure or a diastolic pressure of $100-110 \mathrm{mmHg}$ within a few minutes or hours.

Dillon ${ }^{5}$ suggested a decrease of onethird of the expected blood pressure height in the first 6 hours, another onethird decrease within the next 12-36 hours and onethird of the rest within 2-4 days. In this study after the introduction of clonidine the systolic pressure decreased to $24.3 \%$, the diastolic pressure to $27 \%$ and the MAP to $29.7 \%$ within 6 hours. This was in accordance with the target expected in the literature.

Within 6 hours the diastolic blood pressure decreased to less than $100 \mathrm{mmHg}$ in 11 cases and 3 cases reached this level after 6 hours later. Only in 3 other cases the expected blood pressure could be achieved after 24 hours.

Clonidine as an antihypertensive drug belongs to a group of alpha-adrenergic agonist and has a penetrating activity to the central nervous system and reduces the effect of sympathic system like alpha-methyldopa. Although clonidine did not work directly but the time allotted to decrease the blood pressure was effective to most patients and could be used in emergency cases. Using this drug intravenously in drip form, as in this study, it showed that clonidine was reasonably effective in lowering the blood pressure. In only one patient additional oral captopril was needed because the diastolic pressure did not reached less than $100 \mathrm{mmHg}$. 
The use of clonidine drip in the management of patients with hypertensive crisis have been as far not yet reported in the literature. It had been used as reported in the literature in the form of intravenous bolus.

Using this drug in drip form the lowering of the blood pressure could be easily controlled in order to prevent the serious side effect of hypertension.

\section{CONCLUSION}

1. Clonidine drip was considered reasonably effective to lower the blood pressure in hypertensive crisis patients.

2. The most common cause of hypertensive crisis in children was acute glomerulonephritis.

3. After 6 hours of clonidine drip the systolic blood pressure was decreased to $24.3 \%$, diastolic pressure to $27 \%$ and the MAP $29.7 \%$.

4. The diastolic blood pressure less than $100 \mathrm{mmHg}$ can be achieved after 6 hours of clonidine administration in 11 cases $(64.7 \%), 14$ cases $(82.3 \%)$ after 12 hours and in 3 cases (17.6\%) after 24 hours.

5. The diastolic pressure decreased to less than 100 $\mathrm{mmHg}$ with a dosage of 0.002 clonidine in 3 cases, $0.004 \mathrm{mg}$ in 4 cases and $0.006 \mathrm{mg}$ in 10 cases.

\section{REFERENCES}

1. Alatas H, Wila Wirya IGN, Tambunan T. Management of renal hypertension in children in Jakarta. Proceedings of the $3^{\text {rd }}$ colloquium in Nephrology, Tokyo; 22-23 Oktober 1979: 197-200.

2. Wila Wirya IGN, Alatas H, Tambunan T, Hermanses S, Windiastuti E. Studies of blood pressure and prevalence of hypertension in school children in Jakarta, Pediatr Indones 1988; 28: 183-91.

3. Sidabutar RP, Wiguno P. Hipertensi esensial. Dalam: Soeparman et al eds. Buku Ilmu Penyakit Dalam (jilid II). Jakarta: Balai Penerbit FKUI 1990: 205-23.

4. Kaplan NM. Hypertensive emergencies and urgencies. In: Kaplan H.M., ed. Clinical hypertension, Baltimore: Williams and Wilkins, 1990: 268-82.

5. Dillon MJ. Drug Treatment of hypertension in: Holliday MA, Barratt TM, Vernier RL eds. Pediatric Nephrology $2^{\text {nd }}$ Ed. Baltimore: William \& Wilkins, 1987: 758-65.

6. Alatas H. Krisis hipertensi pada anak dalam: Kumpulan naskah Simposium Nasional Nefrologi Anak II. Surabaya: Ikatan Dokter Anak Indonesia Jawa Timur: 1983: 83-92.

7. Alatas, H. Ensefalopati hipertensif dalam : Pusponegoro HD, Passat J. eds.: Kedaruratan Saraf Anak. Naskah Lengkap Pendidikan Tambahan Berkala Ilmu Kesehatan Anak keXVIII. Jakarta: Balai Penerbit FKUI, 1989: 109-19.

8. Balfe JW, Rance CP. Recognition and management of hypertensive crisis in childhood. Pediatr Clin North Am 1978; 25:159-74.

9. Zimmerman JL. Hypertensive emergencies in Mustafa, I ed Proceedings of the International Symposium in Cardiothoracic Critical Care. Jakarta : Indonesian Society for Critical Care Medicine: 1991: 88-97.

10. Scharer K. Renal hypertension in childhood, Ann Nestle $1984 ; 12: 1-4$. 